\title{
Quantitative and Qualitative identification of Phytochemical Constituents of Sida rhombifolia leaves extract
}

\author{
Anooj E.S, Amrutha T.M, M.Charumathy, Lekshmi Gangadhar
}

\begin{abstract}
Anti-inflammatory, analgesic, antimicrobial, anti-arthritic, antibacterial, antispasmodic, hypoglycaemic and hepatoprotective characteristics of Sida rhombifolia are included in the Malvaceae family. Most of the plant belongs to the Malvaceae family, as they comprise a number of phytochemicals and biological compounds, are potential sources of different medications. This is study on Sida rhombifolia leaf extract's tophytochemical constituen ts. Phytochemical screening results in herbal stan-dardizat ion and preparation and may relate the components to thei $r$ medicinal/pharmacological uses. The qualitative phytochemical analysis has shown that the extract is positive for saponins, flavonoids, alkaloids, phenols and same extract is negative for carbohydrate, tannins, glycosides, cardiac glycosides, terpenoids, coumarins, steroidd phytosteroids, phlobutanins, anthraquinones. Quantitative analysis of phytochemicals includes the estimation of flavonoid, tannin and total content of phenol. The result suggest that the Sida rhombifolia leaves extract consist plenty of phytochemicals beneficial in alternative medical and pharmaceutical industries.
\end{abstract}

Index Terms: Sida rhombifolia, Malvaceae, Phytochemicals, Phytochemical analysis.

\section{INTRODUCTION}

Head

One of the two hundred species in the Sida genus is Sida rho mbifolia (Figure 1).It was discovered in warm and humid are as and dispersed all over the tropics [1]. Sida rhombifolia

Revised Manuscript Received on July 05, 2019.

Dr. M. Charumathy, ${ }^{2}$ Assistant Professor, Department of Biochemistry, Marudhar Kesari Jain College For Women,Vaniyambadi -635751, Tamilnadu, India , sarumathym09@gmail.com

Amrutha T.M, Department of Nanotechnology, Noorul Islam Centre for Higher Education, Kumaracoil, Kanya kumari District. Tamilnadu, India

Anooj E.S, Lekshmi Gangadhar, Xcellogen Biotech INDIA Pvt Ltd, Nagercoil, Tamilnadu, India,xcellogenbiotech@gmail.com belongs to the Malvaceae native to the new world tropics and climatic zone. It's usually referred to as arrow leaf Sida, jellyleaf etc. S. Rhombifolia might be somewhat erect woody, variable yearly or perpetual bush concerning 1.5 meters high with harsh branches and symmetrical hairs. Leaves region unit frightfully factor in get along to $5 \mathrm{~mm}$ by $18 \mathrm{~mm}$, short petiole, rhomboid-lanceolate to pointed, unpleasant towards the most astounding, whole towards the base. The blossoming and develop inside the plant start from september to december. Blossoms are yellow or white, axillary, lone or two by two. The leaves are decreased on the blooming branches. The natural products are discouraged, globose, schizocarpic, encased inside the curl, isolating into one-seeded indehiscent unit. Seeds are dark and wash [2].

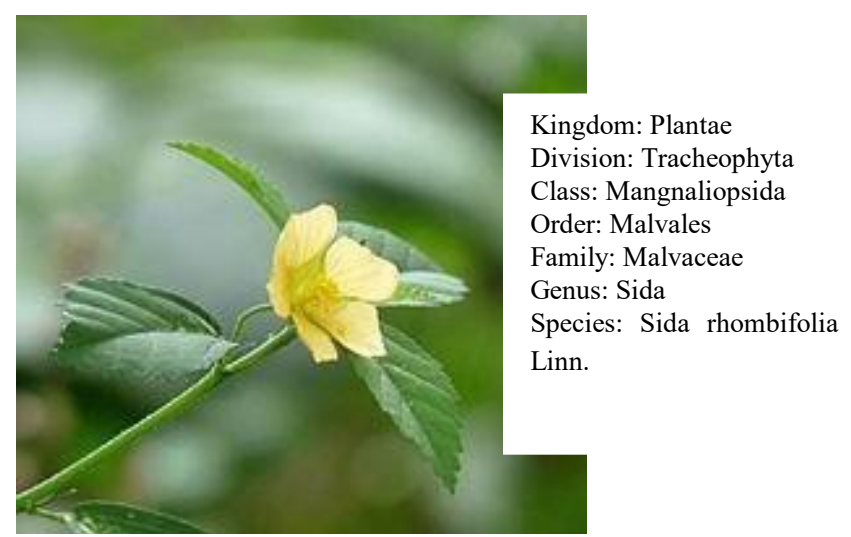

Figure1: Sida rhombifolia

Sida rhombifolia is asserted for the treatment of various dise ases such as rheumatism, seminal weakness and diarrhoea[3]

Sida rhombifolia is far used for treating ulcers, inflammation, swellings and ant nociceptive[4]. S.rhombifoliais thought for its great choice of meditative uses. This plant's infusion is used locall $\mathrm{y}$ to treat skin illnesses and infected wounds[5].The roots are used to treat rheumatism and abdomen illnesses, digestive $\mathrm{d}$ rawback, infectious disease, chickenpox, blood purification and tiredness[6]headache and migraine headache (fruits), fever, infection with gum, inflammation, tonsillitis, cuts, inju ries and ophthalmia[7].

The infusion of dried leaf of $S$. rhombifolia is used for diabetes, chest pain and 


\section{Quantitative and Qualitative identification of Phytochemical Constituents of Sida rhombifolia leaves extract}

diarrhoea on oral administration. S.rhombifolia showed many pharmacological operations, inc luding antibacterial ones, antifungal, anti-arthritic, antiinflammatory, anti-diarrheal, anti-diabetic, wound healing, hypotensive, nephrotoxicity, anti-malarial, antioxidant, hepatoprotective [8]. The World Health Organization (WHO) presently inspires, recommends and encourages traditional remedies in health care plans as they're simply obtainable at low value, relatively harmless and traditionally common[9].

The plant growths leads to the production various chemical compounds are called phytochemicals and refer as "secondary metabolites" that consist, flavonoids, alkaloids, coumarins, tannins, phenols, phlobatannins, anthraquinones, terpenoids, cardiac glycosides, steroid and phytosteroid [10]. It is known that the phytochemical compounds identified have medicinal significance. Alkaloids have been recorded as potent poisons, for instance, and many alkaloids from medicinal plants demonstrate biological activities such as antispasmodic and pharmacological impacts antimalarial, antimicrobial

cytotoxicity, anti-inflammatory[11].Similarly, steroids derive $\mathrm{d}$ from plants are known to have cardiotonic impacts and als o have antibacterial and insecticide properties [12]. Because of their well-known biological activities, they are very often used in drugs. According to research, tannins have antibacterial actions, ant itumor and antiviral [ 13 ]. Other phytochemicals called resp iratory glycosides were handled for congestive heart failure and cardiac arrhythm. [14].

The medical uses S.rhombifolia lies within the bioactive components, that shows diverse physiological properties, could be detected through phytochemical analyses[15]. Therefore, the aim of this study to identifying qualitative and quantitativephotochemistry from the leaf extract of Sida rhombifolia. Phytochemical studies help in standardization of herbal preparation and understanding the importance of phytoconstitients in terms of their medical uses.

\section{MATERIALS AND METHODS}

\subsection{Sample Preparation:}

The blossoming plant of Sida rhombifolia leaves were gathered from street sides and around the Vellore locale, Tamil nadu during December, 2018 .The sample was authenfied from botanical survey of India. Thoroughly washed the leaves with tap water,After which w ashedwith refined water. Air dried and grounded to coarse powder at that stage and $\mathrm{pl}$ aced away in an impermeable compartment.

\subsection{Sequential Extraction:}

Sida rhombifolia leaves about (100gm) of sample and $300 \mathrm{ml}$ of hexane for extraction kept for 24 hours.
The sample was filtered after extraction using whatmann's fil ter paper. The filtered thus obtained was cool and concentrated to dryness. Then dry leaf powder (100gm) was placed in $300 \mathrm{ml}$ of ethyl acetate for added 24 hours in maceration. After 24 hours mixed and then filtered thus obtained was cooled and concentrated to dryness. Then dry powder of leaves in $(100 \mathrm{gm})$ was placed $300 \mathrm{ml}$ of ethanol for 24hours maceration. After 24hours mixed and filtered thus obtained to cool. Then the extraction mixture was filtered and red concentrated of distilling unit. Then its residues were weighed and kept in bottle to use phytochemical and other biological screening methods. Then collected to filtrate.

\subsection{Qualitative Phytochemical Tests:}

\subsubsection{Test for carbohydrate:}

Added to $2 \mathrm{ml}$ of leaf extract $1 \mathrm{ml}$ of molish reagent and a few drops of concentrated sulphuric acid, appearance of purple or reedish shading demonstrates the presence of carbohydrate.Fehling A $1 \mathrm{ml}$ and Fehling B $1 \mathrm{ml}$ boiled for 10 $\mathrm{m}$ inutes, presence of reddish darker (brown) shading.

\subsubsection{Test for tannins:}

Added to $1 \mathrm{ml}$ of leaf extract and $2 \mathrm{ml}$ of $5 \%$ ferric chloride lead to the appearance of dark greenish or dull blue shows the conformation of tannins.

\subsubsection{Test for saponins:}

In a graduated flask, $2 \mathrm{ml}$ of distilled water was add ed to $2 \mathrm{ml}$ of leaf extract and shaken for 15 minutes.Appeara nce of $1 \mathrm{~cm}$ layer of a lather shows the conformation of saponins.

\subsubsection{Test for flavonoids:}

Added $1 \mathrm{ml}$ of $2 \mathrm{~N}$ sodium hydroxide to $2 \mathrm{ml}$ of leaf extract. Yellow shading appearance shows the existence of $\mathrm{fl}$ avonoids.

\subsubsection{Test for alkaloids:}

Added to $2 \mathrm{ml}$ of leaf extract $2 \mathrm{ml}$ of concentrated $\mathrm{H}$ CL. At that point, few drops of Mayer's reagent were added, the appearance of green or white precipitate shows the alkal oid conformation.

\subsubsection{Test for quinones:}

Added $1 \mathrm{ml}$ of concentrated sulphuric acid to $1 \mathrm{ml}$ of leaf extr act. A red color appearance indicates the existence of quinon es.

\subsubsection{Test for phenol:}

Mixed with $1 \mathrm{ml}$ of leaf extract and a few drops of phenol $\mathrm{Ci}$ ocalteacus reagent followed by a few drops of $15 \%$ sodium c arbonate. Blue (or) green appearance.

\subsubsection{Test for glycosides:}


Adding $3 \mathrm{ml}$ of chloroform and $10 \%$ ammonia soluti on to $2 \mathrm{ml}$ of leaf extract contributes to the formation of pink colour shows appearance of glycosides..

\subsubsection{Test for cardiac glycosides:}

Added $2 \mathrm{ml}$ of glacial acetic acid and a few drops of $5 \%$ ferric chloride to $0.5 \mathrm{ml}$ of leaf extract. This was under 1 ayered with $1 \mathrm{ml}$ of concentrated sulphuric acid and dark col ored ring growth at the interface suggests the existence of he art glycosides.

\subsubsection{Test for terphenoids:}

$2 \mathrm{ml}$ of chloroform was added to $0.5 \mathrm{ml}$ of leaf extra ct, then concentrated sulphuric acid was closely added to the red brown color formation at the interface indicating terphe noid existence.

\subsubsection{Test for anthraquinones:}

Added $1 \mathrm{ml}$ of leaf extract and few drops of $10 \%$ of ammonia solution. The appearance of pink color precipitate shows the presence ofanthraquinones.

\subsubsection{Test for coumarins:}

Added $1 \mathrm{ml}$ of leaf extract and $1 \mathrm{ml}$ of $10 \%$ of sodiu $\mathrm{m}$ hydroxide leads to yellow colour formation suggests prese nce of coumarin.

\subsubsection{Test for steroid and phytosteroid:}

Added to $1 \mathrm{ml}$ of leaf extract and equal volume of $\mathrm{c}$ hloroform then exposed with few drops of concentrated sulp huric acid leading to brown ring formation shows the existen ce of steroids and bluish brown ring appearance suggests the existence of phytosteroids.

\subsubsection{Test for phlobatannins:}

Added $1 \mathrm{ml}$ of leaf extract and few drops of $2 \%$ of HCL suggests the existence of phlobatannis, leading to the a ppearance of red color precipitate.

\subsection{Quantitative Phytochemical Tests:}

\subsubsection{Determination of flavonoid content:}

Total flavonoid content was determined in the extract (ethyl acetate) Using this technique mentioned by sankanaka (2005). Aluminum chloride technique used quercetin as normal determined the flavonoid content.

The extract and quercetin were prepared in ethyl acetate $(10 \mathrm{mg} / \mathrm{ml}) .0 .1 \mathrm{ml}$ of extract was blended in test pipes with $0.9 \mathrm{ml}$ of distilled water accompanied by an addition of $75 \mu \mathrm{l}$ of $5 \%$ sodium nitrate.

Added $10 \mu \mathrm{l}$ of $10 \%$ aluminum oxide solution after 6 minutes and mixture was allowed to stand for 5 minutes. After $0.5 \mathrm{ml}$ of $1 \mathrm{M}$ sodium hydroxide was added to the response mixture. The reaction mixture was carried to $2.5 \mathrm{ml}$ distilled water and blended well. The absorbance was immediately evaluated by the spectrometer at 510 $\mathrm{nm}$. A calibration curve was obtained using distinct quercetin concentration and the sample equivalence (QE) was represe nted in the extract's $\mu \mathrm{g} / \mathrm{mg}$.

\subsubsection{Determination of tannin content}

Folinciocalteu technique was used to determine the content o f tannin extract. $0.1 \mathrm{ml}$ of $1 \mathrm{mg}$

leaf extract added to the test tube. Then added $7.5 \mathrm{ml}$ of distilled water and $0.5 \mathrm{ml}$ of folin-ciocalteu reagent, $1 \mathrm{ml}$ of $35 \% \mathrm{Na}_{2} \mathrm{CO}_{3}$.It is diluted up to $10 \mathrm{ml}$ with distilled water. Then shaken well and held for 30 minutes at room temperatu re. Added a collection of standard tannic acid solution (20, 40, $60,80,100)(\mu \mathrm{g} / \mathrm{ml})$. Standard solution absorbance calculated with respect to absorbance of blank at $725 \mathrm{~nm}$ with UV visible spectrometer and the concentration of tannin measured in mg of extract tannic acid equivalence (TE) $\mu \mathrm{g} / \mathrm{mg}$.

\subsubsection{Determination of total phenol content:}

The concentration of phenolic contentintheextract compou nd was found by the calorimetric technique of folin ciocalteuand calculate $\mathrm{d}$ as standard from the calibration curve attained with gallic $\operatorname{acid}(10 \mathrm{mg} / 10 \mathrm{ml})$.

Different test tubewere taken from the standard solution 20$100 \mathrm{~m} \mu \mathrm{l}$ and added.Leaf extract was added to separate test tu bes at concentrated $10 \mathrm{mg} / \mathrm{ml}$ and then folin-ciocalteu dilution $(1: 10)$ of $5 \mathrm{ml}$ was added and mixed thoroughly.0.7 $\mathrm{M}$ sodium carbonate was added in $4 \mathrm{ml}$ quantity followed by mixing and 30minutes incubation. The absorbance was measured at 765 $\mathrm{nm}$ UV visible spectrometer resulting in sample gallic acid e quivalence (GE) $\mu \mathrm{g} / \mathrm{mg}$ extract.

\section{RESULT AND DISCUSSION}

\subsection{Qualitative phytochemical test:}

In addition, the dried powered sample was taken to qualitative testing according to conventional operation for th e identification of phytochemical constituents. 


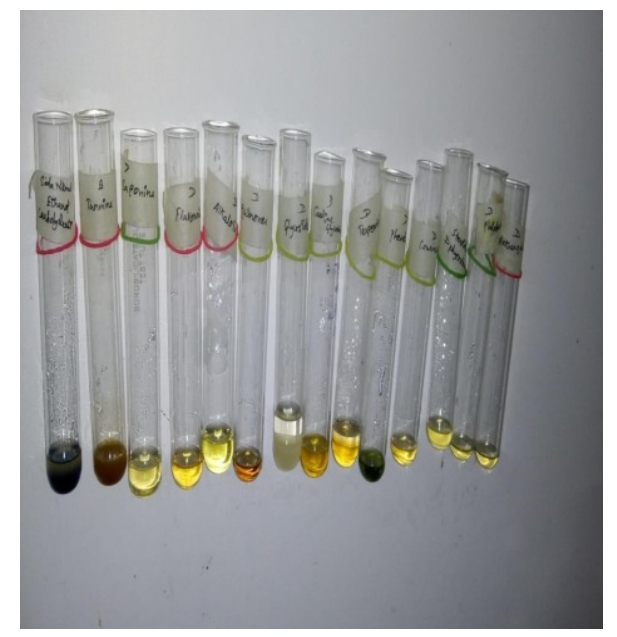

Figure 1: The preliminary phytochemical investigation shows the presence of phytoconstituent such as the saponins, flavonoids, alkaloids, phenols was subjected to qualitative analytical test are present plant extract.

Phytochemical screening of crude hexane, ethylacetate and e thanol extracts from S.rhmbofilia leaf samples discl-osed the existence of certain secondary metabolites such as tannins, saponins, carbohydrates, alkaloids, quinones, flavonoids,glycosides, terpenoids, heart glycosides phenols, coumarins, phytosteroid, anthraquinones, phlobutanins, as shown in Table 1. Sida rhombifolia (L.) leaves have been subjected to the plant's qualitative analytical test.

Flavonoids, steroids, glycosides and alkaloids have been det ected to be the most effective principles in plantThese phyto constituents can be liable for many the pharmacological acti vities such as ant diabetic, cholesterol lowering and wound healing .

\subsection{Quantitative analysis of Sida rhombifolia:}

In addition that, dried powder sample was exposed to quantitative tests for the identified of phytochemical components according to standard procedure. The primary phytochemical investigation showed the occurrence of phytoconstitients flavonoid, tannin and phenolic content. The leaves of Sida rhombifolia was subjected to quantitative analytical tests for the plant.

\subsubsection{Flavonoids estimation:}

Flavonoids are very important because they assist the human body combat disease. Flavonoids ' capacity to behave as powerful antioxidants relies on their molecular structures, hydroxyl group position, and further characteristics in their biochemical structure. As their glycoside they are discovered abundantly in plants [35]
Table 1: Phytochemical screening of the leaf extract of Sida rhombifolia

\begin{tabular}{|c|c|c|c|c|}
\hline Sl. No & Test & $\begin{array}{c}\text { Hexan } \\
\text { e }\end{array}$ & $\begin{array}{c}\text { Ethyl } \\
\text { acetate }\end{array}$ & $\begin{array}{c}\text { Ethano } \\
1\end{array}$ \\
\hline 1. & $\begin{array}{c}\text { Carbo } \\
\text { hydrat } \\
\text { e }\end{array}$ & No & No & No \\
\hline 2. & $\begin{array}{c}\text { Tannin } \\
\mathrm{s}\end{array}$ & No & No & No \\
\hline 3. & $\begin{array}{c}\text { Saponi } \\
\text { ns }\end{array}$ & Yes & Yes & No \\
\hline 4. & $\begin{array}{c}\text { Flavon } \\
\text { oids }\end{array}$ & Yes & No & Yes \\
\hline 5. & $\begin{array}{c}\text { Alkalo } \\
\text { ids }\end{array}$ & Yes & Yes & No \\
\hline 6. & $\begin{array}{c}\text { Quino } \\
\text { nes }\end{array}$ & No & No & No \\
\hline 7. & $\begin{array}{c}\text { Glycos } \\
\text { ides }\end{array}$ & No & No & No \\
\hline 8. & $\begin{array}{c}\text { Cardia } \\
\text { c } \\
\text { glycosi } \\
\text { des }\end{array}$ & No & No & No \\
\hline 9. & $\begin{array}{c}\text { Terpen } \\
\text { oids }\end{array}$ & No & No & No \\
\hline 10 . & $\begin{array}{c}\text { Phenol } \\
\mathrm{s}\end{array}$ & Yes & Yes & Yes \\
\hline 11. & $\begin{array}{c}\text { Couma } \\
\text { rins }\end{array}$ & Yes & No & Yes \\
\hline 12. & $\begin{array}{c}\text { Steroi } \\
\text { ds \& } \\
\text { Phytos } \\
\text { teroids }\end{array}$ & No & Yes & No \\
\hline 13. & $\begin{array}{l}\text { Phloba } \\
\text { tannins }\end{array}$ & No & No & No \\
\hline 14. & $\begin{array}{c}\text { Anthra } \\
\text { quinon } \\
\text { es }\end{array}$ & No & No & No \\
\hline
\end{tabular}

Table 2: Concentration of flavonoids content in Sida rhombifolia (L.) 


\begin{tabular}{|c|c|}
\hline $\begin{array}{c}\text { Quercetin } \\
\text { calibration }\end{array}$ & Absorbance \\
\hline Hexane & $2.57 \%$ \\
\hline Ethanol & $16.85 \%$ \\
\hline
\end{tabular}

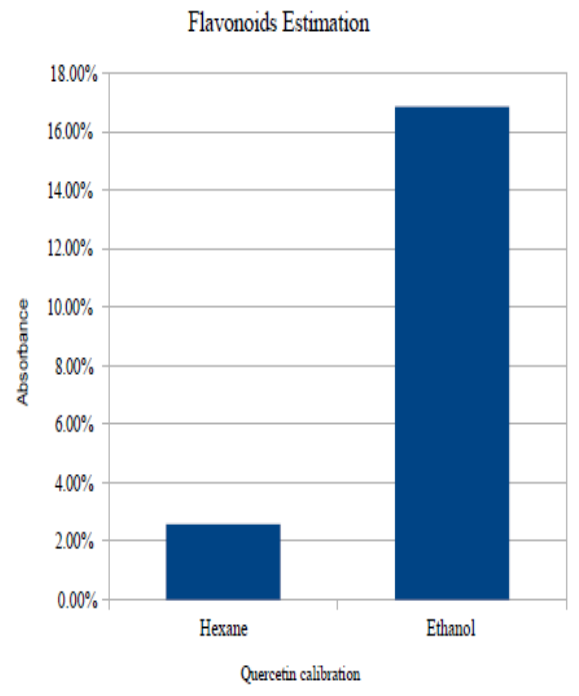

Figure 2: The primary phytochemical analysis of flavonoids in the leaf extract of Sida rhombifolia (L.)

The result clearly indicate that the flavonoid content in the leaf extract of Sida rhombifolia (L.) was found to be more in ethanolic extract (16.85\%) when compared to the hexane $(2.57 \%)$

\subsubsection{Phenol Estimation}

The phenolic compounds are regarded the number of second ary metabolites that contribute to the plant's antioxidant activ ity as a significant group. The existence of phenolic compou nds in the plant shows that as an anti-microbial agent this pla nt may have the ability. Plant polyphenols are the important group of complexes that act as free radical scavengers or main antioxidants, so determining phenolic content in plant extract is justifiable

Polyphenolic compounds, including their functional derivati ves, have an aromatic benzene ring with replaced hydroxyl $g$ roups. These can absorb free radicals and metal ions that can catalyze the formation of ROS that promotes lipid peroxidat ion.

Table 3: Concentration of phenolic content in

Sidarhombifolia $(L)$

\begin{tabular}{|l|l|}
\hline $\begin{array}{l}\text { Gallic acid } \\
\text { calibration }\end{array}$ & Absorbance \\
\hline Hexane & $5.8 \%$ \\
\hline Ethylacetate & $13.8 \%$ \\
\hline Ethanol & 24.8 \\
\hline
\end{tabular}

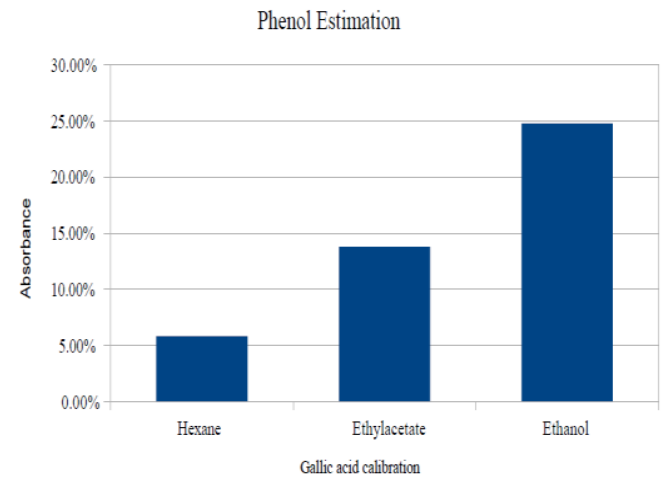

Figure 3: The primary phytochemical analysis of phenol in the leaf extract of Sida rhombifolia (L.)

The result clearly indicate that the phenolic content in the leaf extract of Sida rhombifolia (L.) was found to be more in ethanolic extract (24.8\%) when compared to the hexane (5.8\%) and ethyl acetate(13.8\%)

\section{CONCLUSION}

Sida rhombifolia (L.) encompasses a long history as a meditative plantwith numerous therapeutic applications. Thisresearch was aimed to analyze the effect of Sida rhombifolia (L.) (Family, Malvaceae) leaf extract. The qualitative phytochemical analysis has shown that the extract is positive for saponins, flavonoids, alkaloids, phenols, and same extract negative for carbohydrates, tannins, glycosides, cardiac glycosides, terpenoids, coumartins, steroids \& phytosteroids, phlobutannins, anthraquninones. In this research, the recognized phytochemical compoun ds may be the medically precious bioactive components. Therefore Sida rhombifoila leaf extract could be consid ered as a good source of helpful drugs and further work on isolating, purifying and characterizing these phytoch emical constituents. Thus, the above research concludes that its therapeutic properties may be due to the occurre nce in this plant of certain flavanoid and phenolic comp ounds and other phytochemicals.

\section{REFERENCES}

1. Mabberley DJ, Pignatti-Wikus E, Riedl-Dorn C. Ferdinand Bauer's field drawings of endemic Western Australian plants made at King George Sound and Lucky

Bay, December 1801-January 1802. 
I. Rendiconti Lincei. 2000 Jun 1;11(2):69.

2. Kirtikar KR, Basu BD. Indian Medicinal Plants, Vol. iii: 1968-1969. Lalit Mohan Basu. 1984;40.

3. Rainsford KD, Whitehouse MW. Anti-inflammatory/anti-pyretic salicylic acid esters with low gastric ulcerogenic activity. Agents and actions. 1980 Nov 1;10(5):451-6.

4. Sulaiman MR, Hussain MK, Zakaria ZA, Somchit MN, Moin S, Mohamad AS, Israf DA. Evaluation of the antinociceptive activity of Ficus deltoidea aqueous extract. Fitoterapia. 2008 Dec 1;79(7-8):557-61.

5. Maheshwari JK, Singh KK, Saha S. Ethnomedicinal uses of plants by Tharus in Kheri district. UP, pg. 1980:318-37.

6. Woldeyes S, Adane L, Tariku Y, Muleta D, Begashaw T. Evaluation of antibacterial activities of compounds isolated from Sida rhombifolia Linn. Malvaceae). Nat Prod Chem Res. 2012;1(101):2.

7. Singh A, Dubey NK. An ethnobotanical study of medicinal plants in Sonebhadra District of Uttar, Pradesh, India with reference to their infection by foliar fungi. Journal of Medicinal Plants Research. 2012 Apr 16;6(14):2727-46.

8. Mishra SH, Chaturvedi SC. Antibacterial and antifungal activity of alkaloid of Sida rhombifolia Linn. Indian drugs. 1978.

9. Muanza DN, Kim BW, Euler KL, Williams L. Antibacterial and antifungal activities of nine medicinal plants from Zaire. International Journal of Pharmacognosy. 1994 Jan 1;32(4):337-45.

10. Gupta SR, Nirmal SA, Patil RY, Asane GS. Anti-arthritic activity of various extracts of Sida rhombifolia aerial parts. Natural product research. 2009 May 20;23(8):689-95.

11. Dunstan CA, Noreen Y, Serrano G, Cox PA, Perera P, Bohlin L. Evaluation of some Samoan and Peruvian medicinal plants by prostaglandin biosynthesis and rat ear oedema assays. Journal of Ethnopharmacology. 1997 Jun 1;57(1):35-56.

12. Mullick R, Ranjan SR, inventors; General Electric Co, assignee. Method and system for performing image registration. United States patent US 7,995,864. 2011 Aug 9.

13. Dhalwal K, Shinde VM, Singh B, Mahadik KR. Hypoglycemic and hypolipidemic effect of Sida rhombifolia ssp. retusa in diabetic induced animals. International Journal of Phytomedicine. 2010 Apr $1 ; 2(2)$.

14. Seshathri K, Thiyagarajan T. Antimicrobial Activity of Chewing Sticks of Jimma ,Ethiopia against. Journal of Phytology. 2011 Jul 18.
15. Mishra SH, Varma KC. Preliminary pharmacological investigations of alkaloid of Sida rhombifolia Linn.[India]. Science and Culture. 1979. 